\begin{abstract}
"Mircea cel Batran" Naval Academy Scientific Bulletin, Volume XIX - 2016 - Issue 2 The journal is indexed in: PROQUEST / DOAJ / Crossref / EBSCOhost / INDEX COPERNICUS / DRJI / OAJI / JOURNAL INDEX / I2OR / SCIENCE LIBRARY INDEX / Google Scholar / Academic Keys/ ROAD Open Access I Academic Resources / Scientific Indexing Services / SCIPIO / JIFACTOR
\end{abstract}

\title{
GLOBALIZATION, MODERN TERRORISM AND MEDIA
}

\author{
Edith-Hilde KAITER ${ }^{1}$ \\ ${ }^{1} \mathrm{PhD}$ lecturer "Mircea cel Batran” Naval Academy Constanţa, green_flower19@yahoo.com
}

\begin{abstract}
Modern technology has provided small terrorist groups with a powerful "instrument" - mass media - which willingly or unwillingly serves their needs. As it is more and more believed, the terrorist acts by themselves wouldn't have this impact if it weren't for publicity. Several terrorist organizations realized the potentials of media-oriented terror, in terms of effectively reaching huge audiences. Media seems to promote their deeds efficiently. The impact across media reveals interesting similarities and differences: both press and television led to image changes and heightened the importance attributed to the issue. Press reports were found to be somewhat more effective in forming attitudes and perceptions than television, while exposure to television coverage was more effective in encouraging interpersonal communication. Several differences may be explained by the different functions of each medium, the audience's needs directed to each medium, and the different format and content of presentation in each medium.

The paper deals with the effectiveness or non-effectiveness of media under different circumstances such as war, crisis and terror.
\end{abstract}

Key-words: globalization, terrorism, global media, television, press

The mass media's growing influence in modern societies can no longer be denied. Both theoretical analyses and empirical evidence show that, over time, newspapers, television, and even television programs devoted primarily to entertainment, effectively play a significant role in how the public comes to define and perceive major aspects of political and social reality. Given the importance of the mass media, the question is now: Who shapes the news and according to what standards do they do so? Many radicals still insist that the media are biased in a conservative direction, while other commentators maintain that the various institutional checks created by media organizations insure fairness - if not objectivity in describing world events. All major leadership groups in the United States agree that the media have more influence than any other group in the society and it seems that terrorists use the media to gain national and international attention. ${ }^{1}$

In the days of The Front Page, journalists, like most Americans, went to work after graduating from high school or even before. While some journalists and executives on leading papers were from upper middle-class backgrounds, journalism was most often a source of social mobility for working-class and lower middle-class youth. This pattern changed after World War II. Increasing numbers of young men and women from upper middle-class backgrounds began to seek jobs in journalism and television as a way of partaking of an exciting and creative career and having an impact on society.

\footnotetext{
${ }^{1}$ Stanley Rothman, The Mass Media in Liberal Democratic Societies, New York: Paragon House, 1992, p. 177.
}

Journalists who work for the key national media today are far more likely than businessmen to have come from relatively affluent backgrounds, to have graduated from elite universities, and to be characterized by a liberal and cosmopolitan outlook. ${ }^{2}$ It was found that 45 percent of the staffs of leading media outlets remember their parents' income as above average compared to 31 percent of a sample of business executives at major firms. They were educated at elite universities, but are not scholars. Their careers, moreover, discourage scholarly activity. Operating under rigid schedules, and forced to deal with one breaking story after another, it seems that they do not have the necessary time to investigate material in depth. Since it seems that they lack the time to read many books or to think issues through carefully (also partly due to temperament and choice), journalists' judgments as presented to the public are often based on a very shallow knowledge of the subjects with which they deal. They learn by reading newspapers and journals, and more importantly by interviewing the people they interact with, thus developing a superficial sophistication about various issues which face the country. ${ }^{3}$

It is several people's view that journalists do try to be "fair." The real question, of course, lies in determining what is fair. While equal coverage in a presidential election may constitute fairness, what about scientific controversies? Is it journalistic fairness to give equal time to those who believe that the earth is flat and those who

\footnotetext{
${ }^{2}$ Ibid.

3 Ibid.
} 


\section{"Mircea cel Batran" Naval Academy Scientific Bulletin, Volume XIX - 2016 - Issue 2 The journal is indexed in: PROQUEST / DOAJ / Crossref / EBSCOhost / INDEX COPERNICUS / DRJI / OAJI I JOURNAL INDEX I I2OR / SCIENCE LIBRARY INDEX / Google Scholar / Academic Keys/ ROAD Open Access I Academic Resources / Scientific Indexing Services / SCIPIO / JIFACTOR}

believe that it is round? Probably many people doubt it and so do most journalists.

A better test of the impact of journalists' ideology is probably "accuracy." How accurately do journalists describe events over the long run and what relationship does accuracy bear to journalists' world views? Most critics of the media (from both conservative and radical perspectives) claim that journalists do not describe events accurately. However, the critics' judgments are based on their own views of reality, which is precisely the question at issue. Critics - both conservative and radical - and journalists thus talk past each other. ${ }^{4}$

It was early in the 1970s that several studies revealed the emergence of a new mode of terrorism, the media-oriented terror. As Jenkins concluded in his analysis of international terrorism, "terrorist attacks are often carefully choreographed to attract the attention of the electronic media and the international press. Taking and holding hostages does nothing but increases the drama. The hostages themselves often mean nothing to the terrorists. Terrorism is aimed at the people watching, not at the actual victims. Terrorism is a theater".

However, it seems that modern technology has provided small terrorist groups with a powerful instrument - the mass media - which willingly or unwillingly serves their needs. As Laqueur put it, "the media are the terrorist's best friend; the terrorist's act by itself is nothing, publicity is all." ${ }^{6}$ Several terrorist organizations realized the potentials of media-oriented terror, in terms of effectively reaching huge audiences. A study of incidents of international terrorism revealed a significant increase in terrorist acts that victimize Western nations (though the perpetrators are nonWestern) and are directed to attract the attention of the Western media. No wonder that J.B. Bell argued: "it has become more alluring for the frantic few to appear on the world stage of television than remain obscure guerrillas of the bush." ${ }^{7}$ Terrorist theory was gradually realizing the potency of the mass media. Acts of terrorism were more and more perceived as means of persuasion, when the victim is "the skin on a drum

\footnotetext{
${ }^{4}$ Ibid, p. 179.

${ }^{5}$ B. Jenkins, International Terrorism, Los Angeles: Crescent Publication, 1975, p. 4.

${ }^{6} \mathrm{~W}$. Laqueur, The Futility of Terrorism, Harper's, 1976, p.104.

J.B. Bell, Transnational Terror, Washington D.C.: American Enterprise Institute for Public Policy Research, 1975, p. 85.
}

eaten to achieve a calculated impact on a wider audience." 8

The televised (or internet) spectacle is integral to contemporary insurgent terrorism. The calculating fanatics who planned the 9/11 atrocities clearly knew that the first aircraft crashing into the twin towers would generate a nation-wide, real-time audience for the second plane's stunning arrival. Several critics agreed that a variety of goals were achieved through its choreographed violence: it created fear, anger, and thirst for revenge throughout the US; it demonstrated American vulnerability; it generated political polarization throughout the world - dangerous for humanity, but politically useful to elements on both (discursively constructed) 'sides' in the subsequent 'war on terror'.

Now, several questions appear. For example, if terrorism is a distorted form of communication, can mass-mediated communication also be a form of terror? One common view sees news media as at least unwitting accomplices of insurgent terrorists, by not only spreading their messages and psychological impact, but by enhancing their legitimacy and recruitment efforts. Liebes and Kampf argue that in the changed media ecology (including the emergence of alJazeera) since 9/11, global journalism has turned terrorists into regular sources, and even cultural 'superstars.',

That is a contestable view, at least in the North American context, where mainstream media are far more likely to focus on the destructive actions and future threat of insurgent terrorism, rather than on its grievances or even the social conditions that breed it. Beyond such overtly political/propagandistic functions, dominant media have nurtured a culture of terrorism. Why did so many New Yorkers express a sense of 'surrealism' at the 9/11 destruction of the Twin Towers? Perhaps because the attack was the materialization of a catastrophe already embedded cinematically in the public imagination. ${ }^{10}$

Dominant media are complicit in a culture and a politics of fear. Such a cultural environment creates incentives for politicians and governments to appeal to 'security', military strength and crime crackdowns as a fast track to popularity, and as a

\footnotetext{
${ }^{8}$ Alex Schmid and JFA De Graaf, Violence as Communication: Insurgent Terrorism and the Western News Media, London, 1982, p. 14.

9 Liebes, T. and Kampf, Z., "The P.R. of Terror: How New-Style Wars Give Voice to Terrorists" (2004) in: Allan, S. and Zelizer, B., Reporting War: Journalism in Wartime, London and New York: Routledge, pp. 77-95.

${ }^{10}$ Ibid.
} 
convenient way to avoid climate crisis and other pressing issues that might disrupt business as usual. It is a political culture that fuels the militaryindustrial complex, the private security industry, the small arms trade, a gated community/Fortress America mentality, and a foreign policy that arguably practices state terrorism, economic exploitation, and cultural domination, fostering hatred amongst subordinate populations. Of course, this sounds as a recipe for a cycle of terror and counter-terror. But anyway, what is at the root of media-as-terror? Some see a link forged by technology. Some time ago, Jerry Mander analyzed a host of what he considered to be inherent technological biases in western culture's then-dominant medium, television. TV, he said, favors death, commodities, artificially highlighted events, compressed time, charismatic leaders, fast-paced and fixation-inducing techniques - and war rather than peace: War is better television than peace. It is filled with highlighted moments, contains action and resolution, and delivers a powerful emotion: fear. Peace is amorphous and broad. The emotions connected with it are subtle, personal and internal. These are far more difficult to televise. ${ }^{11}$

That's a plausible argument, so long as we do not 'essentialize' television as a medium. Any international survey would show that TV is quite capable of offering diverse and thoughtful programming. It is not inherently a violencepromoting medium. What is important is the governing logic, the political economy, within which the medium is institutionalized.

It's possible to go still further: media terror isn't only about media representations of violence. Media themselves are a form of structural violence, which Lynch and McGoldrick define as 'a structure, usually understood as a system of political, social or economic relations, [that] creates barriers that people cannot remove...an invisible form of violence, built into ways of doing and ways of thinking,' a form that 'includes economic exploitation, political repression and cultural alienation'. Through the dominant global media, perhaps the world is wired in such a way as to reproduce the social/economic inequalities and cultural hierarchies that fuel the resentment, ignorance and desperation underlying political extremism and insurgent terrorism. ${ }^{12}$ One of the most influential theorists of modern terrorism was the Brazilian Carlos Marighela, whose

11 Mander, Jerry, Four Arguments for the Elimination of Television, New York: Harper Perennial, 1978, p. 323.

12 Jake Lynch and Annabel McGoldrick, Peace Journalism, Gloucestershire (UK): Hawthorn Press, 2005, pp. 59-60.
"Minimanual of the Urban Guerrilla" became a sourcebook for many terrorist movements all over the world. In his publications, Marighela outlined the various uses that can be made of the media: "To kidnap figures known for their artistic, sporting, or other activities who have not expressed any political views may possibly provide a form of propaganda favorable to the revolutionaries.... Modern mass media, simply by announcing what the revolutionaries are doing, are important instruments of the propaganda. The war of nerves, or the psychological war, is a fighting technique based on the direct or indirect use of the mass media...." "The coordination of urban guerrilla action, including each armed action, is the principal way of making propaganda. These actions, carried out with specific and determined objectives, inevitably become propaganda material for the mass communication system. Bank assaults, ambushes, desertion and diverting of arms, the rescue of prisoners, executions, kidnapping, sabotage, terrorism, and the war of nerves, are all cases in point. Airplanes diverted in flight, ships and trains assaulted and seized by guerrillas, can also be solely for propaganda effects." ${ }^{14}$

These views are present in various forms in other terrorist literature and publications. This led several scholars of terrorism to reconceptualize the phenomenon of terrorism in the framework of symbolic communication theory. Thus, for example, Karber suggested a new model of analysis: "As a symbolic act, terrorism can be analyzed much like other media of communication, consisting of four basic components: transmitter (the terrorist), intended recipient (target), message of violence necessitates a victim, whether personal or institutional, but the target or intended recipient of the communication may not be the victim."15 Dowling suggested applying the concept of "rhetoric genre" to modern terrorism, arguing that "terrorists engage in recurrent rhetorical forms that force the media to provide the access without which terrorism could not fulfill its objectives."16

\footnotetext{
${ }^{13}$ Marighela, Carlos, For the Liberation of Brazil, Harmondsworth: Pelican, 1971, pp. 87-90.

${ }^{14}$ Marighela, Carlos, Minimanual of the Urban Guerrilla, J. Mallin, ed., Terror and the Urban Guerrilla, Coral Gables: University of Miami Press, 1971, p. 103.

${ }^{15}$ Karber P., Urban Terrorism: Baseline Data and a Conceptual Framework, Social Science Quarterly, 1971, pp. 527-33.

${ }_{16}$ Dowling R. E., Terrorism and the Media: A Rhetorical Genre, Journal of Communication, 1986, pp. 12-24.
} 
Several studies revealed the impressive success of terrorists in gaining media coverage. Terrorist events are often so newsworthy that the media cannot ignore them. It is quite clear that many terrorist events meet, or are preplanned to meet, these conditions. However, most of the studies focused on amount of coverage as a measure of terrorism's success and not on the effects of this coverage on public opinion.

According to scientists, the lack of studies on the effects of mass-mediated terrorism may be partly explained by the theoretical and methodological complexity of conceptualizing and measuring media effects. Traditional scholarship on this subject has been divided between the "powerful media" paradigm, arguing major media effects, and the "weak media" paradigm which holds that media effects are minimal. Early empirical research on the effectiveness of the media was dominated by the image of an omnipotent media and a mass society. Society was believed to consist of atomized individuals, unconnected to each other and vulnerable to the suggestions, if not dictates, of the media. ${ }^{17}$

However, subsequent empirical evidence suggests that the media are less effective than was previously assumed. The flow of communication is less direct than was once thought: mass media ordinarily do not serve as a sufficient and necessary cause of opinion change but rather functions among and through a nexus of mediating factors. As Berelson put it, "Some kinds of communication on some kinds of issues, brought to the attention of some kinds of people under some kinds of conditions, have some kinds of effects". Two factors were found to limit media influence: audience selectivity (in exposure, perception and retention) and interpersonal influence. No longer viewed as strictly atomistic and passive, audiences of the mass media were increasingly understood to have the autonomy to avoid, resist and twist messages that challenge their preconceptions and attitudes. This selectivity and interpersonal processing of media messages have been found to act as filters of mass mediated influence, contributing to reinforcement rather than change of audience opinions. ${ }^{18}$

As a result, a more complex perception of media effects has evolved, leading scholars of media effects to focus on more specific effects and especially on those which do not trigger defense mechanisms such as selectivity. Concepts such

17 Stanley Rothman, The Mass Media in Liberal Democratic Societies, New York: Paragon House, 1992, p. 180.

18 Berelson B., Communications and Public Opinion, W. Schramm, ed., Mass Communication, Urabana: University of Illinois Press, 1949, p. 500. as climate of opinion, status conferral, cultivation and reconstruction of reality, knowledge gap, or agenda-setting may serve as examples of these specific effects that caused, to some extent, "a return to the concept of powerful mass media." ${ }^{19} \mathrm{It}$ appears that when the media are the sole source of information, and when no predispositions exist (or, at least, when they are not antagonized), the media increases effectiveness in shaping images, attitudes and perceptions. As Noelle-Neumann argues: "Consonance eliminates selective perception and increases the effects of mass media.... The thesis that mass media do not change attitudes but only reinforce them cannot be upheld under conditions of consonance and accumulation." 20

The findings regarding the media's impact on the terrorist' image may be related to all three types of image redefinition. In the specific cases involved, the media served as the sole source of information and interpretation. Thus, the media can form or redefine images. In many terrorist events reported from abroad, the public is dependent on the media for information and interpretation. Unfortunately, the public lacks any established attitudes or perceptions. What is surprising in this study's findings is the imageimproving effect. Before turning to various explanations of this specific "redefinition of image" caused by the media, it must be reiterated that the findings are delimited by the measure of shortterm effects, the use of particular terrorist events that may misrepresent the full domain of such events, and the choice of politically "remote" incidents. However, within these limits, the impact of the "theater of terror" can be emphasized as long as the "show" does not trigger defense mechanisms by creating cognitive dissonance. What is it about media coverage of terrorism that may contribute to its image-improving effect? Several aspects are suggestive.

Media coverage of terrorist events must explain the motive for the cruel and brutal aggression, directed mainly to innocent victims. By looking for a motive and by presenting the political or social background - media reports often rationalize terrorism. Keeping in mind that terrorists are often motivated by a true political, social, or cultural grievance, this reasoning done by reporters, media analysts and, as it often happens, the

\footnotetext{
${ }^{19}$ Noelle-Neumann E., Return to the Concept of Powerful Mass Media, Studies of Broadcasting, 1973, pp. 67-112.$$
{ }^{20} \text { lbid. }
$$ 


\section{"Mircea cel Batran" Naval Academy Scientific Bulletin, Volume XIX - 2016 - Issue 2 The journal is indexed in: PROQUEST / DOAJ / Crossref / EBSCOhost / INDEX COPERNICUS / DRJI / OAJI I JOURNAL INDEX I I2OR / SCIENCE LIBRARY INDEX / Google Scholar / Academic Keys/ ROAD Open Access I Academic Resources / Scientific Indexing Services / SCIPIO / JIFACTOR}

terrorists themselves when being interviewed may lead to sympathy and identification. ${ }^{21}$

Terrorists are dubbed with a rich variety of labels, ranging from murderers to freedom fighters. Some of these labels are loaded with positive values (e.g., liberation movement, popular front, freedom fighters) that may affect the image and attitudes held by a public unacquainted with the issue.

Coverage of terrorist events often highlight the unequal ratio of the small group of terrorists up against many security forces, counterterrorist units, snipers and police, heavily armed with sophisticated weaponry. The fact that most terrorists are ready to sacrifice their lives (and in fact most terrorist attacks leave the terrorist injured or killed), may further enhance the image of the desperate "underdogs". ${ }^{22}$

Victims of terrorist attacks, especially in cases of kidnapping, were sometimes found to associate themselves with the terrorists and their motives and even to help them. This phenomenon, named after a case in Stockholm, Sweden, was partially explained by the victim's surprise to find unexpected humanity in the terrorist. The mass media, which tend to focus on these unexpected terrorist behaviors (human gestures like release of a pregnant woman, stroking the head of a crying child, or giving a helping hand to a frightened elderly hostage), may be themselves subjects of this Stockholm Syndrome, carrying it to their huge audiences. These speculative explanations may serve as hypotheses for systematic content analysis of media coverage of terrorism. Such analysis may reveal those content features which contribute to the impact of mass-mediated terrorism on the public.

However, the comparison of impact across media reveals interesting similarities and differences: both press and television led to image changes and heightened the importance attributed to the issue. Press reports were found to be somewhat more effective in forming attitudes and perceptions than television, while exposure to television coverage was more effective in encouraging interpersonal communication. These differences may be explained by the different functions of each medium, the audience's needs directed to each medium, and the different format and content of presentation in each medium. When considering these attributes, the effectiveness of the press is highlighted. Press reports are more detailed, provide more

\footnotetext{
21 Stanley Rothman, The Mass Media in Liberal Democratic Societies, New York: Paragon House, 1992, p. 182.

22 Ibid.
}

information and analysis, and appeal better to the public's cognitive needs. ${ }^{23}$

Television presentation is more condensed and focuses on the visual, and often dramatic, features of the event. Thus, television is more effective on the emotional rather than the cognitive dimension. Television indeed might be more inherently effective at encouraging interpersonal communication than the press. Exposure to television is more of a group experience while the consumption of newspaper reports tends to be a more isolated experience (a finding revealed by many "uses and gratifications" studies, highlighting the integrative function of television).

Still, in a world where politics and conflict are increasingly mediatized, one need not accept all of the above arguments to acknowledge that dominant national and global media, generically speaking, are too often implicated in relations and acts of violence, and the politics of fear. Is there a way out?

The censorship of terrorist spectacles, in a misguided effort to deprive insurgent terrorists of the publicity they need, is hardly an option. Censorship would undermine a core putative function of media - to assist audiences in 'surveying the environment', obviously including violent assaults on social order. Moreover, a censored press would deepen the shadows around the problem of state terrorism, and sharpen the hierarchies of access that comprise a form of structural violence. In any event, outside of very closed regimes, censorship of terrorist spectacles is not likely to be effective in the era of the Internet and the blogosphere. 
"Mircea cel Batran" Naval Academy Scientific Bulletin, Volume XIX - 2016 - Issue 2 The journal is indexed in: PROQUEST / DOAJ / Crossref / EBSCOhost / INDEX COPERNICUS / DRJI / OAJI I JOURNAL INDEX I I2OR / SCIENCE LIBRARY INDEX / Google Scholar / Academic Keys/ ROAD Open Access I Academic Resources / Scientific Indexing Services / SCIPIO / JIFACTOR

\section{BIBLIOGRAPHY}

[1] BELL, J.B., Transnational Terror, Washington D.C.: American Enterprise Institute for Public Policy Research, 1975.

[2] BERELSON, B., Communications and Public Opinion, W. Schramm, ed., Mass Communication, Urabana: University of Illinois Press, 1949.

[3] DOWLING, R. E., Terrorism and the Media: A Rhetorical Genre, Journal of Communication, 1986.

[4] JENKINS, B., International Terrorism, Los Angeles: Crescent Publication, 1975.

[5] KARBER P., Urban Terrorism: Baseline Data and a Conceptual Framework, Social Science Quarterly, 1971.

[6] LAQUEUR, W., The Futility of Terrorism, Harper's, 1976.

[7] LIEBES, T., Kampf, Z., "The P.R. of Terror: How New-Style Wars Give Voice to Terrorists" (2004) in: Allan, S. and Zelizer, B., Reporting War: Journalism in Wartime, London and New York: Routledge.

[8] LYNCH, Jake, McGoldrick, Annabel, Peace Journalism, Gloucestershire (UK): Hawthorn Press, 2005.

[9] MANDER, Jerry, Four Arguments for the Elimination of Television, New York: Harper Perennial, 1978.

[10] MARIGHELA, Carlos, For the Liberation of Brazil, Harmondsworth: Pelican, 1971.

[11] MARIGHELA, Carlos, Minimanual of the Urban Guerrilla, J. Mallin, ed., Terror and the Urban Guerrilla, Coral Gables: University of Miami Press, 1971.

[12] NOELLE-NEUMANN E., Return to the Concept of Powerful Mass Media, Studies of Broadcasting, 1973.

[13] ROTHMAN, Stanley, The Mass Media in Liberal Democratic Societies, Paragon House, New York, 1992.

[14] SCHMID, Alex, De Graaf, J.F.A., Violence as Communication: Insurgent Terrorism and the Western News Media, London, 1982. 